\title{
What Drives Green Restaurant Patronage Intention?
}

\author{
Booi-Chen Tan \& Peik-Foong Yeap \\ Faculty of Management, Multimedia University \\ Persiaran Multimedia, Cyberjaya 63100, Selangor, Malaysia \\ Tel: 60-3-8312-5721Ｅ-mail: tbchen@yahoo.com
}

Received: September 23, 2011

doi:10.5539/ijbm.v7n2p215

\author{
Accepted: November 11, 2011 \\ Published: January 16, 2012 \\ URL: http://dx.doi.org/10.5539/ijbm.v7n2p215
}

\begin{abstract}
The trends of corporate social responsibility and sustainability drive many firms to adopt green marketing practices through the development of products and services targeted to meet the demand of environmentally conscious consumers. Green movement enables firms to gain competitive advantages, improve ecological performance, reduce operational costs, and enhance corporate image. However, the pressure to adopt environmental management practices in the food service sector is insignificant compared to the manufacturing sector in Malaysia. This disparity is evident despite of the fast growing number of restaurants and widespread habit of eating out, which bring with it an increasingly detrimental environmental impact. Currently, there is limited existing research on the demand for green practices within the food service sector from the consumers' perspectives in Malaysia. This paper reviews the conceptual and empirical literatures and proposes a conceptual framework to examine how attitudes and pro-environmental behaviours influence consumers' intention towards patronising green restaurants. In addition, the theoretical and practical implications are also put forward.
\end{abstract}

Keywords: Attitudes, Pro-environmental behaviour, Intention, Green restaurant, Malaysia

\section{Introduction}

Environmental issues have been the focus of discussion since the last few decades. People are becoming more concerned about the environmental issues and some have translated their environmental concern into pro-environmental behaviour such as recycling, energy saving, water conservation, and green purchase behaviour (Kim, 2002, Kim and Choi, 2003; 2005). As a result, both profit oriented and socially responsible firms have deem this situation as one of the market opportunities and started to adopt the concept of green marketing through developing products or services to meet the demand of environmentally conscious consumers. In view of the trends of sustainability and corporate social responsibility, green marketing is one of the major adoptions in the competitive modern business today. The green movement enables firms to gain competitive advantages and helps to improve the ecological performance, reduce the operational costs and enhance the corporate image (Mensah, 2006; Wan, 2007).

In Malaysia, the Government is constantly seeking to ensure a balanced development between growth and environmental sustainability. The enactments of laws and regulations, incentive schemes and environmental programmes such as cleaner technology, cleaner production, pollution prevention, adoption of the Environmental Management System (EMS), as well as the ISO 14000 series certification (Green Purchasing Network Malaysia, 2003) were launched for the environmental management purposes. In addition, Budget 2010 had allocated RM1.5 billion for soft loans (below-market rate of interest) to companies that supply and use green technology. However, the pressure to adopt environmental management practices in the service sector is insignificant compared to the manufacturing sector (Grove, Fish, Pickett and Kangun, 1996). The academic and marketing researchers usually focused more on the purchase behaviour towards the tangible green products (Tilikidou, 2007; Ramayah, Lee and Mohamad, 2010; Abdul Wahid, Rahbar and Shyan, 2011). Very few studies have been conducted on the ecological initiatives within the lodging sector (Manaktola and Jauhari, 2007; Han, Hsu, Lee, 2009; Han and Kim, 2010); and the studies on the environmental management issues in the food service sector are also lacking, especially from the consumers' perspectives of green restaurants (Hu, Parsa and Self, 2010).

With rising income and structural changes on lifestyle, the habit of eating out and buying takeaways has become more frequent compared to eating at home. In Malaysia, the largest portion of household expenditures is on food consumption (Heng and Guan, 2007). All these can be evidenced from the fact that food-away-from-home expenditures rose from 4.6 percent in 1973 to 10.8 percent in 2004/2005 (Tey, 2008) and the growing number of 
full-service restaurants which reached 9,742 outlets in 2009 (Euromonitor International, 2009). Full-service restaurants offer fine dining with a wide selection of foods and beverages, and table service. In Malaysia, Cleanliness Certificates awarded by the local authorities to restaurants that met the standard for clean premises and hygienic practices serves as one of the tools for attracting customers besides providing excellent quality food and services. However, very little knowledge exists about the demand for green practices within the food service sector, despite the numerous practices such as energy consumption, waste generation, and the usage of non-recyclable products or wrong recycling practices in the restaurants that contribute significantly to the depletion of environment (Schubert, 2008). Hence, there is a good opportunity for restaurants to engage in green practices to distinct and leverage themselves from others, while protecting the environment. Thus, there is a need to investigate and study the consumers' attitudes and intention towards green restaurants from the consumers' perspectives in Malaysia.

The main objective of this paper is to propose a conceptual framework to examine how various attitudes and pro-environmental behaviours influence consumers' intention to patronise green restaurants in Malaysia. The specific objectives are:

- To examine the influence of environmental attitude, attitude towards green behaviour, and attitude towards green practices in restaurants on the intention to patronise green restaurants.

- To examine the influence of pro-environmental behaviours on intention to patronise green restaurants.

- To determine which is the most significant determinant on the intention to patronise green restaurants.

This paper is structured as follows: The first step involves a review of the literatures pertaining to the conceptual theories and empirical findings reported in the past. This leads to the development of the conceptual framework. Finally, the theoretical and practical implications are also put forward.

\section{Literature Review}

\subsection{Green Definitions}

Green marketing can be defined as the process and activities taken by firms through delivering the environmentally friendly goods or services to create customer satisfaction (Soonthonsmai, 2007). The terms green and pro-environmental were used interchangeably by Shrum, McCarty and Lowrey (1995). As such, green behaviours or pro-environmental behaviours refer to the action of an individual or group that contributes to the sustainable or diminished use of natural resources (Halpenny, 2006). Green purchase behaviour was refereed to the behaviour of purchasing and consuming products which have minimal impacts on the environment (Mainieri, Barnett, Valdero, Unipan, and Oskamp., 1997; Tilikidou, 2007) and green product was defined as a product that does not pollute the earth or deplore natural resources, and which could be recycled or conserved (Shamdasani, Chon-Lin and Richmond, 1993). Lastly, Soonthonsmai (2007) defined green consumers as those who are interested in environmental issues and their purchase behaviours are greatly influenced by environmental concerns and other environmental factors (Shrum et al., 1995; Tilikidou, 2007).

\subsection{Green Restaurants}

Green restaurants can be defined as "new or renovated structures designed, constructed, operated, and demolished in an environmentally friendly and energy-efficient manner" (Lorenzini, 1994, pg. 119). Service is intangible in nature, but the restaurant operations depend on the physical components and these tangible aspects of service products are believed to have a major impact on environment (Ismail, Kassim and Zahari, 2010). According to Gilg, Barr and Ford (2005), green restaurant focuses on three Rs (reduce, reuse, recycle) and two Es (energy and efficiency). Engaging in green practices can have significant implications for a restaurant in terms of cost management, market differentiation, as well as environmental protection (Schubert, 2008; Hu et al., 2010).

\subsection{Green Practices in Restaurants}

When restaurants engage in green practices, such practices must be aimed at effectively reducing, the environmental and social problems that arise directly or indirectly from their operations. For example, the adoption of an environmentally friendly management approach helps to reduce solid waste, water consumption, energy consumption, and air pollution (Johnson, 2009; Butler, 2008; Carbonara, 2007). The purchase of eco-friendly products such as sustainable food, nontoxic cleaning and chemical products, and bio-mass agricultural waste products not only helps the restaurant to build a good corporate image, it also expands green practices vertically in the supply chain. For example, it encourages farmers or manufacturers to embrace in green practices in order to supply green products to be used in such restaurants. Hence, it contributes to the economic growth and provides various job opportunities to the nation, and serves as a "win-win" situation for all parties (Ismail et al., 2010). 
In general, restaurant green practices involve the practices of using biodegradable products, saving energy and natural resources actively, purchasing energy saving equipment, reducing and recycling waste, and engaging in environmental protection programmes (Schubert, 2008). Green Restaurant Association (GRA) is a non-profit organization in the USA that provides convenient and cost-effective ways for restaurants to become more environmentally responsible (www.dinegreen.com). The GRA offers 3 types of Certification options for existing restaurants, new builds, and events and listed seven concepts as the environmental guidelines that cover a wide spectrum of different green practices. The seven environmental guidelines are as below:

(a) Energy efficiency and conservation

(b) Water conservation and efficiency

(c) Recycling and compositing

(d) Purchasing sustainable, local, and organic foods

(e) Pollution prevention

(f) Use of non-toxic and chemical products

(g) Sustainable furnishings and building materials (only apply to new builds)

\subsection{General Attitude: Theoretical Concept and Empirical Studies}

Weigel (1983, p. 257) defines attitude as "an enduring set of beliefs about an object that predisposes people to behave in particular ways toward the object". It refers to the "psychological tendency that is expressed by evaluating a particular entity with some degree of favour or disfavour" (Eagle and Chaiken 1993, p.1). The Theory of Reasoned Action (Fishbein and Ajzen 1975) is the popular attitude theory used to discuss the attitude-behaviour relationship. It implies that a specific attitude is a relatively strong predictor of a single behaviour on a particular attitude object, and the use of general attitudes to predict specific behaviour is invalid. Most importantly, attitude is a strong predictor to the behavioural intention, and behaviour intention leads to the actual behaviour.

In the context of environmental studies, the relationship between attitude and behavior has produced inconclusive results (Berger and Corbin, 1992; Cleveland, Kalamas and Laroche, 2005; Gupta and Ogden, 2006; Bedrous, 2007). Past studies have revealed that environmental attitude was the direct predictor of pro-environmental intention and behaviour (Ellen, 1994; Roberts, 1996; Straughan and Roberts, 1999; Kim, 2002; Meinhold and Malkus, 2005; Milfont, 2007; Majláth, 2008; Lopez and Cuervo-Arango, 2008) and the green products purchase commitments are often based on environmental attitudes (Martin and Simintiras, 1995; Grunert and Juhl, 1995; Chan, 1996; Schlegelmich et al., 1996; Chan, K. 1999; Tanner and Kast, 2003; Kim and Choi, 2003; 2005; Fraj and Martinez, 2007; Tilikidou; 2007). However, some of the researchers also commented that there is a gap between attitude and behaviour because the results of green purchases have often been disappointing (Maineiri et al., 1997; Peattie, 2001; Gupta and Ogden, 2006).

\subsection{Specific Attitude: Attitude towards Green Behaviour and Restaurant Green Practices}

Attitude towards green behaviour involves the four-dimensionality structure of attitudes which are the perceived importance of pro-environmental behaviour, inconvenience of environmental consequences, the severity of environmental problems, and the level of responsibility of corporations (Laroche et al., 2001; McCarty and Shrum, 1994; Roberts, 1996). Han et al. (2009) examined the hotel consumers' eco-friendly decision-making process and reported that attitude towards green behaviour in a single variable was a significant predictor on the overall image of green hotels. The findings implied that customers who have favorable attitudes toward green behaviour and positive images of green hotels are willing to stay, to recommend, and to pay more for a green hotel. Subsequently, Han et al. (2010) had confirmed that the four-dimensionality structure of attitudes are generally associated with eco-friendly intentions towards the green hotels, and the importance of being environmentally friendly had a greater impact on intentions to visit and to spread by word-of-mouth. Attitude was positively and significantly associated with revisit intention towards the green hotel (Han and Kim, 2010) and the travel destination (Lam and Hsu, 2004). These findings implied that an increase in favorable attitude will result in an increase in the likelihood of revisiting a green hotel and traveling intention.

Nevertheless, there is a growing amount of evidences indicating the interest of researchers within the green restaurant context recently. Hu et al. (2010) investigated the effects of consumers' knowledge of restaurant's environmental friendly practices, environmental concern, and ecological behaviour on consumers' intention to patronise a green restaurant. The results from the study indicated that the effects of all these three variables on consumers' intention to patronize a green restaurant were found significant. More specifically, Schubert (2008) and Szuchnicki (2009) had explored the consumer attitudes towards various areas of green practices in restaurants. Schubert (2008) reported the univariate results on the attitude and willingness to pay for green 
restaurant separately, however the bivariate relationship between these two variables had not been addressed. On the other hand, a significant positive relationship between return intention and a restaurant with some green practices as well as a return intention and a certified green restaurant were found (Szuchnicki, 2009). Both types of studies are found to be limited in the Malaysian context.

\subsection{Behavioural Intention}

According to Oliver (1997), behavioural intention is defined as an affirmed likelihood to engage in a certain behavior. It can be grouped into two categories (Smith, Haugtvedt and Petty, 1994); economic behavior intentions such as repeat purchase behavior (Anderson and Mittal, 2000), willingness to pay more and switching behavior (Zeithaml et al., 1996); and social behavior intentions such as complaint behavior (Johnston, 1998, Nyer, 1999) and word of mouth communication (Szymanski and Heanrd, 2001; Wright et al., 1996). Whereas, Zeithaml et al. (1996) adopted the variables such as loyalty, switch to others, willingness to pay more, response to external and internal factors to evaluate the customer behavior intention. Similarly, Boulding, Kalra, Staelin and Zeithaml (1993) identified repurchase intention and word of mouth (WOM) behavior to evaluate customer's intention. In the absence of measures of actual behavior, Zeithaml et al. (1996) view behavioral intentions as indicators that signal whether customers will remain with or defect from the company.

As both green purchases in the manufacturing or service sector are still new and niche in the market, most of the existing studies therefore only based on the intention to purchase rather than re-purchase intention to predict the actual behaviour. Chan (2001) confirmed the mediated role of green purchase intention between green purchase attitude and green purchase behaviour. However, the types of green purchase attitudes were not clearly specified in this study. The popularity of attitude-intention analysis can be evidenced from numerous environmental purchase related studies (Kalafatis, Pollard, East and Tsogas, 1999; Tarkiainen and Sundqvist, 2005; Vermeir and Verbeke, 2007).

In the service sector, the studies from Han et al. (2010) as well as Han et al. (2009) both analysed the intention to visit, to recommend, and willingness to pay more for the green hotel. Han and Kim (2010) conducted a study from the customer satisfaction perspective to examine its influence on the behaviour intention to revisit the green hotel. Intention to revisit a restaurant which engages in green practices and the intention to revisit a Certified Green Restaurant were based on the conditions when the green restaurants are absent in the market (Szuchnicki, 2009). It is vital to examine the intention to patronise a green restaurant for future marketing strategy planning, especially for those restaurants that are intending to change their practices or deciding to venture into the food service sector. Inevitably, the price of most green products or green services is at a premium, as such, willingness to pay is the popular variable in the measurement of behavioural intention in most of the environmental purchase related studies (Laroache et al., 2001, Tsen, Phang, Haslinda and Rita, 2006; Szuchnicki, 2009). Nevertheless, $\mathrm{Hu}$ et al. (2010) indicated that future research on the the customers' patronage intentions towards a green restaurant should be conducted from other countries given the differences in values and cultures, in spite of limited empirical evidences.

As a result, a proposed theoretical framework is presented in figure based on the theoretical and empirical literatures discussed. It aims to examine how various attitudes and pro-environmental behaviours influence intention and subsequently helps the researchers to determine the most significant predictor on such intention in the green restaurant context.

\section{Theoretical Implications}

Sun and Wilson (2008) suggested that both types of attitudes (general and specific) should be studied together in an empirical research, rather than isolating them. However, the combination of various attitude components as outlined in this study to predict a specific type of pro-environmental intention or behaviour is still limited within the context of green restaurants. The findings are expected to confirm which is the most appropriate attitude predictor on behaviour intention, to close the attitude-behaviour gap (Weigel and Newman, 1976; Roberts and Bacon, 1997). Other attempts have been made in the marketing and consumer behaviour literatures to identify determinants on pro-environmental behaviour as well as in a specific type of behaviour such as green purchase behaviour (Kim and Choi, 2005; Tilikidou, 2007; Ramayah et al., 2010). However, this study uses the pro-environmental behaviour as an independent variable rather than a dependent variable to predict the specific pro-envirommental intention. This yields an in-depth understanding on the association between the various type of environmental related behaviours, and serves as a good indication of potential customer segmentation criteria. Besides, Tilikidou and Delistavrou (2006) revealed that those who are engaged in one type of non-purchasing pro-environmental behavior are more likely to engage in another type as well, and Tilikidou (2007) suggested that the environmental related behaviourals should be combined together in a study, rather than isolating them. 


\section{Practical Implications}

The joint cooperations among policy makers, business players, and customers are the major factor in fostering the success of environmental protection. The result is a "win-win" situation that brings benefits to all parties.

\subsection{Policy makers}

Attention and effort in combating the environmental problems should be attended equally both to the manufacturing and service sectors. Green restaurant certificates aligned with the environmental guidelines can be awarded to those restaurants that meet the requirement of sustainable practices in operating the restaurants. Such certified green restaurants from the local authority would stand to gain higher trust compared to other self-claimed environmental friendly restaurants. Ideally, incentives schemes or subsidies, and various environmental programmes should be organised to encourage the adoption of environmentally friendly management approaches by restaurant operators.

\subsection{Business players}

Restaurants that are early entrants to the green market segment stands to gain a greater future competitive advantage as they establish themselves in the public's mind as pioneers in the pro-environment cause. A large number of customers show increased favorable attitude towards the green firms indicating their intention to purchase and pay more for environmentally friendly products or services (Manoktola and Jauhari, 2007; Han et al., 2009; Han et al., 2010). Thus, an understanding towards various attitudes components and their effects on intention formation towards the green restaurant enables the restaurant operators to identify the significant predictor on such intentions. More efforts can be made to communicate green restaurant practices to the public to promote the patronage of green restaurants. Thus, it encourages more activie participation for green consumption among people in the nation. By educating and enhancing people's attitudes, green restaurants will leverage themselves to a competitive position in the niche segment, and will gain a greener and more socially responsible corporate image.

Generally, firms are interested to operate in a more sustainable manner, provided by doing so it enables them to differentiate and establish themselves from other businesses. If restaurant patrons show a favorable intention towards patronising green restaurants, this outcome would surely stimulate the establishments of green restaurants. To operate the restaurant, demand towards the tangible aspect of service products directly encourages the production and supply of environmental friendly products from the manufacturing sector, as well as providing the economic values to the farmers to produce sustainable food; which are organically and locally grown food, and to recycle the agricultural wastes and reproduce them into the usable products such as tableware items.

\subsection{Restaurant patron}

Restaurant patron is one who patronises and dines at the restaurant. Excellent food and service quality, pleasant ambience conditions plus the environmental friendly practices at the restaurant provides a distinct dining experience especially to those who are environmentally conscious.

\subsection{Society well-being}

The joint efforts and cooperation from all parties are needed to generate more sustainable and responsible consumption behaviour among the society and produce a healthier environment.

\section{Conclusion}

The fast growing number of restaurants and widespread eating-out habits in Malaysia, effectively results in a significant aggravation on the environment. There is thus a high need for both academic and marketing researchers to focus their future studies more on the food service sector. This group of study has been largely neglected over the last few decades. Therefore, this study proposes a theoretical framework to examine the influence of environmental factors from three aspects of attitudes variables (i.e., attitude towards the environment, attitude towards green behaviours, and attitude towards restaurant green practices) as well as various aspects of pro-environmental behaviours/green behaviours on the behavioural intention to patronise green restaurants.

\section{References}

Abdul Wahid, N. Rahbar, E., \& Tan, S.S. (2011). Factors Influencing the Green Purchase Behavior of Penang Environmental Volunteers. International Business Management, 5(1). 38-49. http://dx.doi.org/10.3923/ibm.2011.38.49

Anderson, W. E., \& Mittal, V. (2000). Strengthening the Satisfaction Profit Chain. Journal of Service Research, 3(2). 107-120. http://dx.doi.org/10.1177/109467050032001 
Bedrous, A.V. (2007). Environmental Concern and Pro-environmental Behaviours: The Relationship Attitudes, Behaviours, and Knowledge. Department of Sociology, University of Nebraska-Lincoln.

Berger, I.E., \& Corbin, R.M. (1992). Perceived Consumer Effectiveness and Faith in Others as Moderators of Environmentally Responsible Behaviours. Journal of Public Policy and Marketing, 11(2). 79-89.

Boulding, W., Kalra, A., Staelin, R., \& Zeithaml, V. (1993). A Dynamic Process Model of Service Quality: Form Expectations to Behavioral Intentions. Journal of Marketing Research, 30. 7-27. http://dx.doi.org/10.2307/3172510

Butler, S.M., \& Francis, S. (1997). The Effects of Environmental Attitudes on Apparel Purchasing Behaviour. Clothing and Textiles Research Journal, 15 (2). 76-85.

Carbonara, J. (2007). Foodservice goes green. Foodservice Equipment and Supplies, 60(9). 48-54.

Chan, K. (1999). Market Segmentation of Green Consumers in Hong Kong. Journal of International Consumer Marketing, 12(2). 7-24. http://dx.doi.org/10.1300/J046v12n02_02

Chan, R.Y.K. (2001). Determinants of Chinese consumers' Green Purchase Behaviour. Psychology and Marketing, 18 (4). 389-413. http://dx.doi.org/10.1002/mar.1013

Chan, T.S. (1996). Concerns for Environmental Issues and Consumer Purchase Preferences: A Two-country Study. Journal of International Consumer Marketing, 9. 43-55. http://dx.doi.org/10.1300/J046v09n01_04

Cleveland, M., Kalamas, M., \& Laroche, M. (2005). Shades of Green: Linking Environmental Locus of Control and Pro-environmental Behaviours. Journal of Consumer Marketing, 22(4). 198-212. http://dx.doi.org/10.1108/07363760510605317

Eagly, A., \& Chaiken, S. (1993). The Psychology of Attitudes. New York: Harcourt Brace Jovanovich.

Ellen, P.M. (1994). Do We Know What We Need to Know? Objective and Subjective Knowledge Effects on Pro-ecological Behaviours. Journal of Business Research, 30(1). 43-52. http://dx.doi.org/10.1016/0148-2963(94)90067-1

Fishbein, M., \& Ajzen, I. (1975). Belief, Attitude, Intentions, and Behaviour: An Introduction of Theory and Research. Reading, MA: Addison-Wesley.

Fraj, E., \& Martinez, E. (2007). Ecological Consumer Behaviour: An Empirical Analysis. International Journal of Consumer Studies, 31(1). 26-33. http://dx.doi.org/10.1111/j.1470-6431.2006.00565.x

Gilg, A., Barr, S., \& Ford, N. (2005). Green Consumption or Sustainable Lifestyles? Identifying the Sustainable Customer. Futures, 37. 481. http://dx.doi.org/10.1016/j.futures.2004.10.016

Green Purchasing Network Malaysia. (2003). An introductory study on green purchasing activities in Malaysia. $1-39$.

Grove, S.J., Fisk, R.P., Pickett, G.M., \& Kangun, N. (1996). Going Green in the Service Sector: Social Responsibility Issues, Implications and Implementation. European Journal of Marketing, 30(5). 56 - 66. http://dx.doi.org/10.1108/03090569610118777

Grunert, S.C., \& Juhl, H.J. (1995). Values, Environmental Attitudes, and Buying of Organic Foods. Journal of Economic Psychology, 16. 39-62. http://dx.doi.org/10.1016/0167-4870(94)00034-8

Gupta, S., \& Odgen, D.T. (2006). The Attitude-behavior Gap in Environmental Consumerism. APUBEF Proceedings, Fall.

Halpenny, E.H. (2006). Examining the Relationship of Place Attachment with Pro-environmental Intentions. Proceedings of the 2006 Northeastern Recreation Research Symposium. GTR-NRS-P-14.

Han, H., \& Kim, Y. (2010). An Investigation of Green Hotel Customers' Decision Formation: Developing An Extended Model of the Theory of Planned Behavior. International Journal of Hospitality Management, 29(4). 659-668. http://dx.doi.org/10.1016/j.jhm.2010.01.001

Han, H., Hsu, L.T., \& Lee, J.S. (2009). Empirical Investigation of the Roles of Attitudes towards Green Behaviours, Overall Image, Gender, and Age in Hotel Customers' Eco Friendly Decision Making Process. International Journal of Hospitality Management, 28. 519-528. http://dx.doi.org/10.1016/j.ijhm.2009.02.004

Hu, H.H., Parsa, H.G., \& Self, J. (2010). The Dynamics of Green Restaurant Patronage. Cornell Hospitality Quarterly, 51(3). 344-362. http://dx.doi.org/10.1177/1938965510370564

Ismail, A., Kassim, A., \& Zahari, M.S. (2010). Responsiveness of restaurateurs towards the implementation of environmentally-friendly practices. South Asian Journal of Tourism and Heritage, 3(2): 1-10. 
Johnson, R. (2009). Organisational Motivations for Going Green for Profitability Versus Sustainability. Business Review, 13(1). 22-28.

Johnston. (1998). The Effect of Intensity of Dissatisfaction on Complaining Behavior. Journal Consumer Satisfaction, Dissatisfaction, and Complaint Behaviour, 11. 69-77.

Kalafatis, S.P., Pollard, M. East, R., Tsogas, M.H. (1999). Green marketing and Ajzen's Theory of Planned Behaviour: A Cross-market Examination. Journal of Consumer Marketing, 16. 441-460. http://dx.doi.org/10.1108/07363769910289550

Kim, Y. (2002). The Impact of Personal Value Structures on Consumer Proenvironmental Attitudes, Behaviours and Consumerism: A Cross-cultural Study. Doctoral Dissertation, College of Communication Arts and Sciences, Michigan State University.

Kim, Y., \& Choi, S. (2003). Antecedents of Proenvironmental Behaviours: AnExamination of Cultural Values, Self-efficacy, and Environmental attitudes. International Communication Association, Marriott Hotel, San Diego, CA. [Online] Available: http://www.allacademic.com/meta/p111527_index.html.

Kim, Y., \& Choi, S.M. (2005). Antecedents of Green Purchase Behaviour: An Examination of Collectivism, Environmental Concern and PCE. Advances in Consumer Research, 32. 592-59.

Lam, T., \& Hsu, C. H. C. (2004). Theory of Planned Behavior: Potential Travelers from China. Journal of Hospitality and Tourism Research, 28(4). http://dx.doi.org/10.1177/1096348004267515

Laroche, M., Bergero, J., \& Barbarot-Forleo, G. (2001). Targeting Consumers Who are Willing to Pay More for Environmentally Friendly Products. Journal of Consumer Market, $18.503-520$. http://dx.doi.org/10.1108/EUM0000000006155

Lee, H.S.H., \& Tan, A.K.G. (2007). Examining Malaysian Household Expenditure Patterns on Food-Away-From-Home. Asian Journal of Agriculture and Development, Southeast Asian Regional Center for Graduate Study and Research in Agriculture. 1. 11-24.

Lopez, A.G., \& Cuergo-Arango, M.A. (2008). Relationship among Values, Beliefs, Norms and Ecological behaviour. Psicpthema, 20(4). 623-629.

Lorenzini, B. (1994). The Green Restaurant, Part II: Systems and Service. Restaurant and Institutions, 104(11). 119-136.

Mainieri, T., Barnett, E., Valdero, T., Unipan, J., \& Oskamp, S. (1997). Green Buying: The Influence of Environmental Concern on Consumer Behaviour. Journal of Social Psychology, 137(2). 189-204. http://dx.doi.org/10.1080/00224549709595430

Majlath, M. (2008). What are the Main Psychographic Differences between Persons Behave in an Environmentally Friendly Eay and Those Who Do Not? MEB 2008- $6^{\text {th }}$ International Conference on Management Enterprise and Benchmarking, May 30-31, 2008. Budapest, Hungary.

Manaktola, K., \& Jauhari, V. (2007). Exploring Consumer Attitude and Behaviour towards Green Practices in the Lodging Industry in India. International Journal of Contemporary Hospitality Management, 19(5). 364-377. http://dx.doi.org/10.1108/09596110710757534

Martin, B., \& Simintiras, A.C. (1995). The Impact of Green Product Lines on the Environment: Does What They Know Affect How They Feel? Marketing Intelligence and Planning, 13(4). 16-23. http://dx.doi.org/10.1108/02634509510088991

McCarty, J.A., \& Shrum, L.J. (1994). The Recycling of Solid Wastes: Personal and Cultural Values and Attitudes about Recycling as Antecedents of Recycling Behaviour. Journal of Business Research, 30. 53-62. http://dx.doi.org/10.1016/0148-2963(94)90068-X

Meinhold, J. L., \& Malkus, A. J. (2005). Adolescent Environmental Behaviours: Can Knowledge, Attitudes, and Self-efficacy Make a Difference? Environment and Behaviour, 37.511 - 532 . http://dx.doi.org/10.1177/0013916504269665

Milfont, T. L. (2007). Psychology of Environmental Attitudes: A cross-cultural Study of Their Content and Structure. Unpublished doctoral dissertation, University of Auckland, Auckland, New Zealand.

Nyer, P. (1999). Cathartic Complaining as a Means of Reducing Consumer Dissatisfaction. Journal of Consumer Satisfaction, Dissatifaction and Complaint Behaviour, 12: 15-25.

Oliver, R.L. (1997). Satisfaction: A Behavioral Perspective on the Consumer. Boston: McGraw-Hill.

Peattie, K. (2001). Golden Goose or Wild Goose? The Hunt for the Green Consumer. Business Strategy and the 
Environment, 10. 187-199. http://dx.doi.org/10.1002/bse.292

Ramayah, T., Lee, J. W. C., \& Mohamad, O. (2010). Green Product Purchase Intention: Some Insights from a Developing Country. Resources, Conservation and Recycling, 54(12). 1419-1427. http://dx.doi.org/10.1016/j.resconrec.2010.06.007

Roberts, J.A. (1996). Green consumers in the 1990s: Profile and implications for advertising. Journal of Business Research, 36. 217-231. http://dx.doi.org/10.1016/0148-2963(95)00150-6

Roberts, J.A., \& Bacon, D.R. (1997). Exploring the Subtle Relationships between Environmental Concern and Ecologically Conscious Consumer Behaviour. Journal of Business Research, 40(1).79-89.

Schlegelmilch, B.B., Bohlen, G.M., \& Diamantopoulos, A. (1996). The Link Between Green Ppurchasing Decisions and Measures and of Environmental Consciousness. European Journal of Marketing, 30(5). 35-55. http://dx.doi.org/10.1108/03090569610118740

Schubert, f. (2008). Exploring and predicting consumers' attitudes and behaviours towards green restaurants. The Degree Master's of Science in the Graduate School of The Ohio State University.

Shamdasani, P., Chon-Lin, G., \& Richmond, D. (1993). Exploring GreenConsumers in an Oriental Culture: Role of Personal and Marketing Mix. Advances in consumer research, 20. 488-493.

Shrum, L.J., McCarty, J.A., \& Lowrey, T.M. (1995). Buyer Characteristics of the Green Consumer and Their Implications for Advertising Strategy. Journal of Advertising, 24(2). 71-76.

Smith, S.M., Haugtvedt, C.P., \& Petty, R.E. (1994). Attitudes and Recycling: Does the Measurement of Affect Enhance Behavioral Prediction. Psychol. Mark, 11(4). 359-374. http://dx.doi.org/10.1002/mar.4220110405

Soonthonsmai, V. (2007). Environmental or Green Marketing as Global Competitive Edge: Concept, Synthesis, and Implication. EABR (Business) and ETLC (Teaching) Conference Proceeding, Venice, Italy.

Straughan, R.D., \& Roberts, J.A. (1999). Environmental Segmentation Alternatives: A Look at Green Consumer Behaviour in the New Millennium. Journal of Consumer Marketing, 16(6). 558-75. http://dx.doi.org/10.1108/07363769910297506

Sun, J., \& Wilson, V.L. (2008). Assessing General and Specific Attitudes in Human Learning Behaviour: An Activity Perspective and A Multilevel Modeling Approach. Educational and Psychological Measurement, 66. 245-261.

Szuchnicki, A.L. (2009). Examining the Influence of Restaurant Green Practices on Customer Return Intention. Master of Science in Hotel Administration, William F.Harrah College of H.A, University of Nevada, Las Vegas.

Szymanski, D.M., \& Henard, D.H. (2001). Customer Satisfaction: A Meta Analysis of the Empirical Evidence. J. Acad Mark. Sci, 29(1). 16-35.

Tanner, C., \& Kast, S.W. (2003). Promoting Sustainable Consumption: Determinants of Green Purchases by Swiss Consumers. Psychology \& Marketing, 20(10). 883-902. http://dx.doi.org/10.1002/mar.10101

Tarkiainen, A., \& Sundqvist, S. (2005). Subjective Norms, Attitudes and Intentions of Finnish Consumers in Buying Organic Food. British Food Journal, 107(11). 808-822. http://dx.doi.org/10.1108/00070700510629760

Tilikidou, I. (2007). The Effects of Knowledge and Attitudes upon Greeks' Pro-environmental Purchasing Behaviour. Corporate Social Responsibility and Environmental Management, $14.121-134$. http://dx.doi.org/10.1002/csr.123

Tilikidou, I., \& Delistavrou, A. (2006). Types and Influential Factors of Consumers' Non Purchasing Ecological Behaviours. Business Strategy and the Environment, 18. 61-78.

Tsen, C.H., Phang, G., Haslinda, H., \& Merlyn Rita, B. (2006). Going Green: A Study of Consumers' Willingness to Pay for Green Products in Kota Kinabalu. International Journal of Business and Society.

Vermeir, I., and Verbeke, W. (2007). Sustainable Food Consumption among Young Adults in Belgium: Theory of Planned Behaviour and the Role of Confidence and Values. Ecological Economics, 64(3). 542-552. http://dx.doi.org/10.1016/j.ecolecon.2007.03.007

Wan, P.Y.K. (2007). The Use of Environmental Management as a Facilities Management Tool in the Macao Hotel Sector. Facilities, 25(7/8). 286 - 295. http://dx.doi.org/10.1108/02632770710753325

Weigel, R.H. (1983). Environmental Attitudes and Prediction of Behaviour. In N.R. Feimer and E.S. Geller (Eds). Environmental Psychology: Directions and Perspectives (pp. 257-287). New York, Praeger.

Weigel, R.H., \& Newman, L.S. (1976). Increasing Attitude-behaviour Correspondence by Broadening the Scope of the Behavioural Measure. Journal of Personality and Social Psychology, 33(6). 793-802. 
http://dx.doi.org/10.1037/0022-3514.33.6.793

Wright, R.E., Perkins, D, Alston, S., Heitzig, S., Meyer-Smith, J., \& Palmer, J.C. (1996). Effects of Dissatisfying Experiences on Repatronage Intentions and Negative Word-of-mouth Behavior of University Students. Journal of Consumer Satisfaction, Dissatisfaction, and Complaint Behaviour, 9. 221-228.

Zeithaml, V.A., Berry, L.L., \& Parasuraman, A. (1996). The Behavioural Consequences of Service Quality. Journal of Marketing, 60, 31-46. http://dx.doi.org/10.2307/1251929

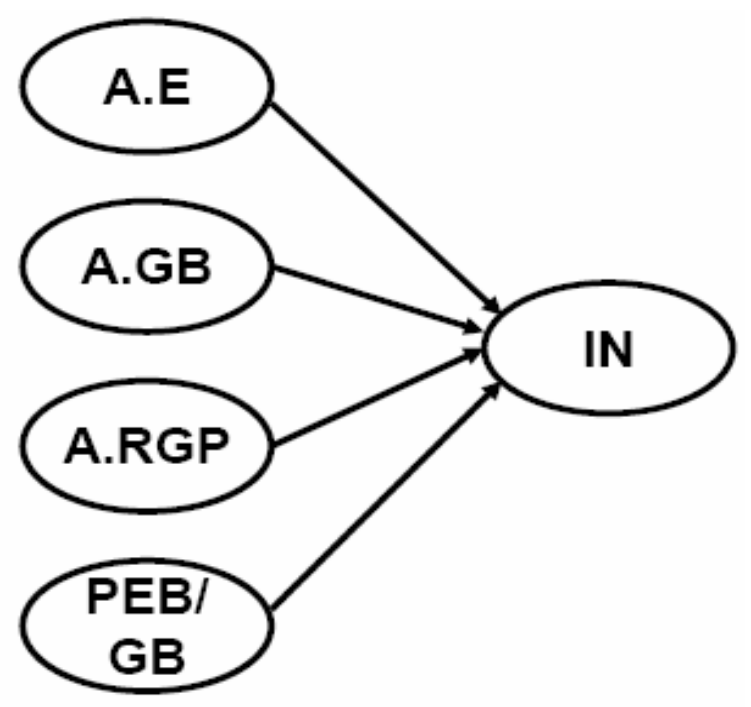

Figure 1. A Conceptual Framework of Consumers' Attitudes and Intention to Patronise Green Restaurants (Adapted from Fishbein and Ajzen (1975); Laroche et al. (2001): Tsen et al. (2006); Het al. (2009); Han et al. (2010); Hu et al. (2010)

(A.E= Attitude towards environment; $\mathrm{A} . \mathrm{GB}=\mathrm{Attitude}$ towards green behaviour; A.RGP= Attitude towards restaurant green practices; $\mathrm{PEB}=$ pro-environmental behaviour/green behaviours; $\mathrm{IN}=$ Intention to patronise green restaurants) 